\title{
EL DERECHO CONSTTTUCIONAL A LA PRESUNCIÓN DE INOCENCIA EN PERÚ Y MÉXICO, ASÍ COMO SU RELACIÓN CON LOS DEMÁS DERECHOS CONSTITUCIONALES
}

\section{The constitutional right to the presumption of innocence in Peru and Mexico, and his relation with other constitutional rights}

\author{
Hesbert Benavente Chorres ${ }^{1}$ \\ Maestro en Derecho Penal por la \\ Universidad Nacional Mayor de San Marcos (Perú) \\ estudiobenavente@yahoo.com
}

RESUM EN: El presente estudio consiste, en primer lugar, en el análisis del derecho constitucional a la presunción de inocencia y el trato que recibe en los sistemas jurídicos de Perú y M éxico. Para ello, se ha tomado en cuenta lo regulado en la Constitución Política de los citados países, su regulación en las leyes secundarias, su análisis en la jurisprudencia y doctrina tanto peruana como mexicana. En segundo lugar, se ha planteado la relación entre la presunción de inocencia con otros derechos constitucionales: libertad, honor, propiedad y a un juicio previo; donde señalamos la presencia en los países antes citados de ciertas figuras en el ámbito del proceso penal que flexibilizan y ponen en peligro los mencionados derechos constitucionales; por lo que, el legislador debe tomar las medidas de corrección respectivas.

PALABRASCLAVE: Presunción de inocencia, derechos constitucionales, Perú y M éxico.

ABSTRACT: The present study consists, first, of the analysis of the constitutional right to the presumption of innocence and the treatment that receives in the juridical systems of Peru and M exico. It has been considered regulation of the Political Constitution its secondary laws, the jurisprudence of both, Peruvian and Mexican jurispru-

1 Doctorante en Derecho por la Universidad Autónoma del Estado de México Miembro del Centro de Investigación en Ciencia Jurídica, Justicia Penal y Seguridad Pública de la Universidad Autónoma del Estado de México. Presentado el artículo con fecha 17 de marzo de 2009 y aprobado con fecha 6 de mayo de 2009. 
dence and doctrine. Secondly, the relation has appeared between the presumption of innocence with other constitutional rights: freed om, honour, property and to a previous judgment; where we indicate the presence constitutional rights adapt and put in danger; for what, the legislador must act according to his own criteria.

KEWWO RDS: Presumption of innocence, constitutional rights, Peru and M exico.

El proceso penal se construye sobre la presunción de inocencia del infractor que conlleva una presunción de falsedad de lo denunciado por la víctima, por lo que conviene recordar que el proceso debería ser un diálogo, que intentara integrar las distintas verdades. ${ }^{2}$

\section{INTRODUCCIÓN}

En la actualidad, se aprecia un continuo desarrollo del Derecho constitucional, concretamente en el ámbito de los derechos constitucionales. ${ }^{3}$ Frente a ello, el objetivo del presente estudio es analizar, en concreto, el derecho a la presunción de inocencia y su relación con otros derechos constitucionales como por ejemplo la libertad personal, el honor, la propiedad y a un juicio previo.

Sin embargo, por las características del presente trabajo, de corte comparativo, se analizará, por un lado, el trato que en el Perú se le da al derecho a la presunción de inocencia, debiéndose recordar que el Perú, por mandato del artículo 430 de la Constitución Política peruana de 1993, es un Estado unitario, lo cual implica un solo centro de poder político que extiende su accionar a lo largo de todo el territorio de la repúbli$\mathrm{ca}$, mediante sus agentes y autoridades locales, delegadas de ese mismo poder central; ${ }^{4}$ además cuenta con una sola Constitución Política que rige en todo el país y a la cual se hayan sometidas todas las autoridades y habitantes del mismo.

Por otro lado, estudiaremos la experiencia mexicana con relación a la presunción de inocencia, debiéndose recordar que en M éxico, su sistema político-jurídico es el federal, ${ }^{5}$ el cual, y en torno al tema que nos ocupa, exige el estudio tanto de la Cons-

2 Cita de Manuela Carmena. Ver: Varona MARTínez, Gerna (1998): La mediación reparadora como estrategia de control social: una perspectiva criminológica (Comares, Granada), p. 180.

3 Por ejemplo, en el caso peruano, se tiene el reconocimiento al denominado derecho constitucional a la verdad, a raíz de la sentencia dictada por la Corte Interamericana de Derechos Humanos, en el caso Castillo Páez vs. Perú.

4 A demás cuenta con un solo poder legislativo que legisla para todo el país; un poder judicial, que aplica el derecho vigente a todo el territorio del Estado y que en su seno se establece una Corte Suprema de Justicia, la cual tiene jurisdicción a nivel nacional, un solo poder ejecutivo.

5 Sobre el "federalismo mexicano", consúltese los siguientes textos: CÁrdenAS GArCí, Jaime (2004): México: 
titución Política de los Estados Unidos M exicanos, así como aquellas dictadas por las entidades federativas (a excepción del Distrito Federal, la cual no cuenta con una Constitución Política).

A simismo, este estudio comparativo viene precedido por nuestra toma de postura sobre el concepto y contenido del derecho a la presunción de inocencia, que nos permitirá luego relacionarlo con otros derechos constitucionales. Finalmente, y como excurso del presente trabajo, se realizará una reflexión en torno a las decisiones de la Corte Interamericana de Derechos Humanos referidas a la materia que nos ocupa.

\section{CONCEPTO DE PRESUNCIÓN DE INOCENCIA}

En sus orígenes, la inocencia se tomó como un estado de pureza absoluta; la lectura fue ideológica: se afirma que las personas al nacer llegan al mundo inocentes, y ese estado pervive en su existencia hasta la muerte. La aplicación en el proceso penal de esta idea se transmite con igual intensidad: sólo la sentencia judicial puede variar el estado de inocencia. Y por eso cuando el juez "absuelve", declara y confirma dicho estado de inocencia; ${ }^{6}$ mientras que la "condena" es constitutiva, pues a partir de ello nace un estado jurídico nuevo.

Luigi Lucchini señalará que la presunción de inocencia es un "corolario lógico del fin racional asignado al proceso" y la "primera y fundamental garantía que el procesamiento asegura al ciudadano: presunción juris, como suele decirse, esto es, hasta prueba en contrario".

Ferrajoli determina que la presunción de inocencia expresa a lo menos dos significados garantistas a los cuales se encuentra asociada que son "la regla de tratamiento del imputado, que excluye o restringe al máximo la limitación de la libertad personal" y "la regla del juicio, que impone la carga acusatoria de la prueba hasta la absolución en caso de duda". ${ }^{8}$

Para Nogueira A Icalá, la presunción de inocencia es así el derecho que tienen todas las personas a que se considere a priori como regla general que ellas actúan de acuerdo a la recta razón, comportándose de acuerdo a los valores, principios y reglas del

A la luz de los modelos federales (Boletín Mexicano de Derecho Comparado, № 110, México D.F.), pp. 479-510. CARMAGnanI, Marcello (1993): Federalismos Latinoamericanos (Fondo de Cultura Económica, México D.F.), pp. 135-137.

6 La expresión "estado de inocencia" es empleada por Gozaine, quien señala que le parece difícil explicar que una persona se presuma inocente cuando se le tiene anticipadamente por culpable (por ejemplo, cuando se le dicta el procesamiento -que es un juicio de probabilidad incriminante-) aplicándole una medida cautelar como la prisión preventiva, pareciéndole una contradicción, Cfr. Gozaínı, Osvaldo Alfredo (1999): Derecho procesal constitucional (Belgrano, Buenos Aires), p. 227.

7 LucCHINI, Luigi (1995): Elemento di procedura penale (Barbera, Florencia), p. 15.

8 FerRajol, Luigi (2001): Derecho y razón (5a edición, Trotta, Madrid), p. 551. 
ordenamiento jurídico, mientras un tribunal no adquiera la convicción, a través de los medios de prueba legal, de su participación y responsabilidad en el hecho punible determinada por una sentencia firme y fundada, obtenida respetando todas y cada una de las reglas del debido y justo proceso, todo lo cual exige aplicar las medidas cautelares previstas en el proceso penal en forma restrictiva, para evitar el daño de personas inocentes mediante la afectación de sus derechos fundamentales, además del daño moral que eventualmente se les pueda producir. ${ }^{9}$

Gozaine indica que el principio de inocencia es un derecho del imputado, pero nunca una franquicia para su exculpación. Esto significa que la producción probatoria y el sistema de apreciación que tengan los jueces integran, en conjunto, el principio de razonabilidad que se espera de toda decisión judicial. ${ }^{10}$

Al respecto, consideramos a la presunción de inocencia como una garantía individual, ${ }^{11}$ como un derecho público contenido en la Constitución, a favor de las personas, que exige que sea ante la autoridad que esté (de competencia penal o no) y ante el procedimiento que se le sujete (igualmente, penal o no), no se considere verosímil la atribución de cargos relacionados con la comisión de delitos, salvo decisión contraria emitida por un tribunal competente dentro de la observancia del debido proceso, ${ }^{12}$ así como, el ser considerados como excepcionales aquellas medidas que restringen la libertad del imputado o sus demás derechos constitucionales. Es un poderoso baluarte de la libertad individual para poner freno a los atropellos a ella y proveer a la necesidad de seguridad jurídica. ${ }^{13}$

\section{EL DERECHO A LA PRESUNCIÓN DE INOCENCIA EN PERÚ Y MÉXICO}

Para el desarrollo del presente estudio se van a comparar los ordenamientos jurídicos mexicano y peruano en torno a:

9 Nogueira AlCALÁ, Humberto (2005): “Consideraciones sobre el derecho fundamental a la presunción de inocencia" (Revista lus et Praxis, № 11, Universidad de Talca), pp. 221-222.

10 Gozaínı, Osvaldo Alfredo (2006): "La presunción de inocencia. Del proceso penal al proceso civil" (Revista Latinoamericana de Derecho, Año III, № 6, Universidad Nacional Autónoma de México, México D.F.), p. 158.

11 Las garantías individuales son derechos públicos que deben ser respetados por las autoridades, limitaciones en el ejercicio de sus funciones, y son derechos subjetivos, pues otorgan una acción personal para lograr que la autoridad no viole los derechos garantizados por la Constitución. Cfr. GUILLÉN LóPEZ, Raúl (2003): Las garantías individuales en la etapa de averiguación previa (Porrúa, México D.F.), p. 98.

12 En la legislación comparada, es interesante lo que establece el artículo 12 de la Constitución de El Salvador: "TODA PERSONA A QUIEN SE IM PUTE UN DELITO, SE PRESUM IRÁ INOCENTE MIENTRAS NO SE PRUEBE SU CULPABILIDAD CONFORME A LA LEY Y EN JUICIO PÚBLICO, EN EL QUE SE LE ASEGUREN TODAS LAS GARANTÍAS NECESARIAS PARA SU DEFENSA".

13 Claría Olmedo, Jorge (1960): Tratado de derecho procesal penal, Tomo I (Ediar S.A., Buenos Aires), p. 232. 
a) La recepción legislativa del derecho a la presunción de inocencia.

b) El tratamiento jurisprudencial del derecho a la presunción de inocencia.

c) El derecho a la presunción de inocencia y su relación con otros derechos constitucionales

A continuación, desarrollaremos estos temas.

\subsection{La recepción legislativa del derecho a la presunción de inocencia}

En lo que respecta a M éxico, el derecho a la presunción de inocencia, a pesar que ha sido mencionado tanto por la jurisprudencia como por la doctrina mexicana, no se encontraba previsto en alguna norma de Derecho penal o de procesal penal, y menos aún a nivel constitucional; solamente estaba señalado en aquellos instrumentos internacionales suscritos por México.

Esta situación conllevó que, en los textos adjetivos tanto a nivel federal como de las entidades federales, se exija al Ministerio Público que, para ejercer la acción penal, haya acreditado "plenamente" la existencia del cuerpo del delito -que vendría ser los elementos del tipo penal-, así como la responsabilidad del imputado o indiciado. ${ }^{14}$

Y esta acreditación plena tenía como marco la Constitución Federal de los Estados Unidos M exicanos, que en varios de sus articulados establecía la acreditación del cuerpo del delito y la responsabilidad del indiciado -así, por ejemplo, lo establecía el artículo 16o constitucional en torno a los requisitos para que el Juez expida orden de aprehensión-.

Es decir, aun antes del dictado de una sentencia firme, el Ministerio Público y el Juez, realizaban sus actos procesales a sabiendas que el ilícito penal, materia de proceso, ya estaba acreditado, así como la responsabilidad del imputado. En efecto, solamente con la presencia de actos o diligencias de investigación, y por imperio de la ley, ya se prejuzgaba la comisión de un delito y la responsabilidad del indiciado.

Sin embargo, esta situación cambia a raíz de la reforma a la Constitución Federal el 19 de junio del 2008. ${ }^{15}$ En efecto, se reformó el artículo 20 o constitucional, inciso B, fracción I, donde se reemplaza la figura de la libertad provisional bajo caución ${ }^{16}$ por el derecho a la presunción de inocencia. ${ }^{17}$

14 Como ejemplo, tenemos los aún vigentes, artículo 134으 del Código Federal de Procedimientos Penales y el artículo 286 bis del Código de Procedimientos Penales para el Distrito Federal.

15 A raíz de esta reforma, se adopta el modelo acusatorio con tendencia a lo adversarial, así como se establece la etapa de juicio oral -inexistente en México- como fase central del nuevo proceso penal. Asimismo, se establecen determinadas medidas para la lucha contra la delincuencia organizado; se reestructura el sistema penitenciario, así como, la justicia juvenil; igualmente, se reformulan los principios y derechos de los sujetos procesales en torno al nuevo modelo adoptado.

16 Artículo 20, inciso B, fracción I, texto anterior: "Inmediatamente que lo solicitó, el Juez deberá otorgarle la libertad provisional bajo caución, siempre y cuando no se trate de delitos en que, por su gravedad, la ley expresamente prohíba conceder este beneficio. En caso de delitos no graves, a solicitud del Ministerio Público, el Juez podrá negar la libertad provisional, cuando el inculpado haya sido condenado con anterio- 
Ello originó la modificación de todos los artículos de la Constitución Federal que, para la procedencia de una determinada figura procesal, exigían la acreditación plena del cuerpo del delito y la responsabilidad del indiciado.

A simismo, conlleva la adecuación de los códigos de procedimientos penales tanto federal como de las entidades federativas al nuevo marco constitucional; siendo los primeros en responder a este llamado los códigos de Oaxaca, ${ }^{18} \mathrm{Chihuahua}^{19} \mathrm{y}$ el recientemente publicado Código de Procedimientos Penales del Estado de México ${ }^{20}$ (promulgada el 9 de febrero del 2009 y que entrará en vigencia, en forma progresiva, el primero de agosto de los corrientes).

A hora bien, una situación paradójica ocurre en el Derecho constitucional de las entidades federativas mexicanas. En efecto, en el federalismo mexicano, cada uno de

ridad, por algún delito calificado como grave por la ley o, cuando el Ministerio Público aporte elementos al Juez para establecer que la libertad del inculpado representa, por su conducta precedente o por las circunstancias y características del delito cometido, un riesgo para el ofendido o para la sociedad".

17 Artículo 20으, inciso B, fracción I, texto reformado: "A que se presuma su inocencia mientras no se declare su responsabilidad mediante sentencia emitida por el juez de la causa.

18 Artículo 50. "El imputado será considerado y tratado como inocente en todas las etapas del proceso y en la aplicación de la ley penal, mientras no se declare su culpabilidad por sentencia firme, conforme a las reglas establecidas en este Código.

En caso de duda, se estará a lo más favorable para el imputado.

Ninguna autoridad pública podrá presentar a una persona como culpable ni brindar información sobre ella en ese sentido hasta la sentencia condenatoria.

En los casos de quienes se encuentren sustraídos a la acción de la justicia, se admitirá la publicación de los datos indispensables para su aprehensión por orden judicial.

El juez o el tribunal limitará por auto fundado y motivado la intervención de los medios de comunicación masiva cuando la difusión pueda perjudicar el normal desarrollo del proceso o exceda los límites del derecho a recibir información".

19 Artículo 50. "El imputado deberá ser considerado y tratado como inocente en todas las etapas del proceso, mientras no se declare su culpabilidad por sentencia firme, conforme a las reglas establecidas en este Código.

En caso de duda, se estará a lo más favorable para el imputado.

En la aplicación de la ley penal son inadmisibles las presunciones de culpabilidad.

Ninguna autoridad pública podrá presentar a una persona como culpable, ni brindar información sobre ella en ese sentido, hasta la sentencia condenatoria.

En los casos de quienes se encuentren sustraídos de la acción de la justicia, se admitirá la publicación de los datos indispensables para su aprehensión por orden judicial.

El Juez o el Tribunal limitará por auto fundado y motivado la intervención de los medios de comunicación masiva, cuando la difusión pueda perjudicar el normal desarrollo del proceso o exceda los límites del derecho a recibir información".

20 Artículo 6‥ "El imputado deberá ser considerado y tratado como inocente en todas las etapas del proceso, mientras no se declare su culpabilidad por sentencia firme, conforme a las reglas establecidas en éste código.

En la aplicación de la ley penal son inadmisibles las presunciones de culpabilidad.

Ninguna autoridad pública podrá presentar a una persona como culpable ni brindar información sobre ella en ese sentido hasta la sentencia condenatoria.

En los casos de quienes se encuentren sustraídos de la acción de la justicia, se admitirá la publicación de los datos indispensables para su aprehensión por orden judicial.

El juez o el tribunal limitará la intervención de los medios de comunicación masiva cuando la difusión pueda perjudicar el normal desarrollo del proceso o exceda los límites del derecho a recibir información". 
los Estados, a excepción del Distrito Federal, puede contar, además de la Constitución Federal, de una propia, interna o estatal carta magna; cuyas cláusulas no deben ser incompatibles al texto federal.

Frente a ello, las entidades federativas lo que han optado es por legislar, en sus constituciones, aquellas figuras no contempladas en la federal pero que no se la oponen, así como, desarrollar o dotarle de un mayor contenido a aquellas que si están reguladas en la Constitución Federal.

En ese sentido, en lo que respecta al derecho constitucional a la presunción de inocencia, las entidades federativas no lo han regulado en sus constituciones y por el contrario han apelado a la figura denominada: cláusula genérica, como el que encontramos, por ejemplo, en el artículo 50 de la Constitución Política del Estado de M éxico: "En el Estado de México todos los individuos son iguales y tienen las libertades, derechos y garantías que la Constitución Federal, esta Constitución y las leyes del Estado establecen". ${ }^{21}$

21 Igualmente encontramos esta cláusula en las siguientes Constituciones:

Artículo 2ํ de la Constitución Política del Estado de Aguascalientes: “Todo individuo gozará en el Estado de las garantías que otorga la Constitución Federal y tendrá los derechos y obligaciones establecidas por las leyes locales".

Artículo 70 de la Constitución Política del Estado de Baja California: "El Estado de Baja California acata plenamente y asegura a todos sus habitantes las garantías individuales y sociales consagradas en la Constitución Política de los Estados Unidos M exicanos, así como los demás derechos que otorga esta Constitución".

Artículo 70 de la Constitución Política del Estado de Baja California Sur: “En el Estado de Baja California Sur todo individuo gozará de las garantías que otorga la Constitución General de la República, las cuales no podrán restringirse ni suspenderse, sino en los casos y con las condiciones que ella misma establece. Igual protección asume respecto de los derechos fundamentales que, en ejercicio de su soberanía, consagra en este cuerpo Constitucional".

Artículo 60 de la Constitución Política del Estado de Campeche: "Además de lo que la Constitución Política de los Estados Unidos M exicanos prescribe sobre derechos garantizados para los habitantes de la República, los del Estado de Campeche gozarán de los demás derechos que la presente Constitución les otorga".

Artículo 70 de la Constitución Política del Estado de Coahuila de Zaragoza: "Todos los que habiten o residan, así sea accidentalmente en el territorio de Coahuila, gozan de las garantías que otorga la Constitución General de la República y que confirma la presente".

Artículo 1 으 de la Constitución Política del Estado de Colima: El Estado de Colima reconoce, protege y garantiza a toda persona, el goce de sus derechos consignados en la Constitución General de la República y los establecidos en esta Constitución".

Artículo 40 de la Constitución Política del Estado de Chiapas: "Toda persona gozará de las garantías individuales y sociales que otorga la Constitución Política de los Estados Unidos Mexicanos y que la presente Constitución reitera; garantías que no podrán restringirse o suspenderse, sino en los casos y con las condiciones que la primera de dichas constituciones establece".

Artículo 4을 le la Constitución Política del Estado de Chihuahua: "En el Estado de Chihuahua, toda persona gozará de los derechos que establecen esta Constitución y la Federal".

Artículo 1o de la Constitución Política del Estado de Durango: "En el Estado de Durango todas las personas gozan de los derechos públicos individuales y de los derechos públicos sociales que la Constitución Federal les otorga, los que no podrán suspenderse ni restringirse si no en los casos y condiciones previstos en la misma. disfrutan además de las garantías que esta Constitución establece".

Artículo 1 o de la Constitución Política del Estado de Guanajuato: "En el Estado de Guanajuato todas las 
Esta situación, no invalida el actual tratamiento legislativo a la presunción de inocencia, dado que, basta que esté presente en la Constitución Federal como en los instrumentos internacionales suscritos por M éxico, para que cada uno de los estados adecue el proceso penal al marco de este derecho constitucional.

personas gozan de la protección que les otorgan las garantías establecidas por la Constitución Política de los Estados Unidos Mexicanos; por esta Constitución y sus Leyes Reglamentarias".

Artículo 1 ㅇ de la Constitución Política del Estado de Guerrero: "En el Estado de Guerrero toda persona gozará de las garantías que otorga la Constitución Política de los Estados Unidos M exicanos y de las señaladas en la presente Constitución",

Artículo 4을 de la Constitución Política del Estado de Hidalgo: “En el Estado de Hidalgo, todo individuo gozará de las garantías que otorga la Constitución Política de los Estados Unidos M exicanos, las cuales no podrán restringirse ni suspenderse, sino en los casos y condiciones que ella misma establece".

Artículo 4ㅇ de la Constitución Política del Estado de Jalisco: "Toda persona, por el solo hecho de encontrarse en el territorio del Estado de Jalisco, gozará de los derechos que establece esta Constitución, siendo obligación fundamental de las autoridades salvaguardar su cumplimiento.

Se reconocen como derechos de los individuos que se encuentren en el territorio del Estado de Jalisco, los que se enuncian en la Constitución Política de los Estados Unidos M exicanos, así como los contenidos en la Declaración Universal de los Derechos Humanos, proclamada por la A samblea General de las Naciones Unidas y en los tratados, convenciones o acuerdos internacionales que el Gobierno Federal haya firmado o de los que celebre o forme parte".

Artículo 1 o de la Constitución Política del Estado de Michoacán: "En el Estado de Michoacán de Ocampo todo individuo gozará de las garantías que otorga la Constitución Política de los Estados Unidos Mexicanos, así como de los demás derechos establecidos en esta Constitución y en las leyes que de ambas emanen".

Artículo 2 - de la Constitución Política del Estado de M orelos: “El Estado de M orelos reconoce y asegura a todos sus habitantes, el goce de las garantías individuales y sociales contenidas en la Constitución Política de los Estados Unidos Mexicanos y en la presente Constitución y, acorde con su tradición libertaria, declara de interés público la aplicación de los artículos 27 y 123 de la Constitución Fundamental de la República y su legislación derivada".

Artículo 70, fracción X de la Constitución Política del Estado de Nayarit: "Los demás derechos a que se refiere el Título primero, Capítulo I, de la Constitución General".

Artículo $2^{\circ}$ de la Constitución Política del Estado de Querétaro: “A demás de los derechos que establece la Constitución Política de los Estados Unidos M exicanos, en el Estado de Querétaro toda persona, por el sólo hecho de encontrarse en su territorio, gozará de los que establece esta Constitución, siendo obligación fundamental de las autoridades salvaguardar su cumplimiento".

Artículo 12 ㅇ de la Constitución Política del Estado de Quintana Roo: "El Estado de Quintana Roo asegura para sus habitantes el goce irrestricto de las garantías individuales y sociales consignadas en la Constitución Política de los Estados Unidos Mexicanos. Igual protección asume respecto de los derechos fundamentales que, en ejercicio de su soberanía, consagra esta Constitución".

Artículo 70 de la Constitución Política del Estado de San Luís de Potosí: “En el Estado de San Luís Potosí la protección de los derechos de sus habitantes y la permanente búsqueda del interés público son la base y objeto de las instituciones políticas y sociales.

Para la convivencia armónica de sus habitantes, queda asegurado el goce irrestricto de todas las garantías individuales y sociales consagradas en la Constitución Política de los Estados Unidos M exicanos, las que el Estado adopta como propias. Las autoridades estatales y municipales deberán respetar y hacer respetar tanto dichas garantías como los derechos humanos, conforme lo dispongan las leyes reglamentarias y ordinarias respectivas.

Artículo $1^{\circ}$ de la Constitución Política del Estado de Sonora: “Los Derechos del Hombre son la base y el objeto de las instituciones sociales. En el Estado de Sonora todo individuo gozará de las garantías que otorga la Constitución Política de los Estados Unidos Mexicanos. En consecuencia, las autoridades, los funcionarios y empleados del Estado y Municipios tienen la ineludible obligación de respetar y hacer 
En ese orden de ideas, a raíz de la reforma a la Constitución Federal del 19 de junio del 2008 , se le ha dado una mayor potencialidad a la presunción de inocencia, al establecerse lo siguiente:

(1) El M inisterio Público al momento de ejercer la acción penal contra el imputado y consignarlo ante el Juzgado penal respectivo (a fin que expida el respectivo auto de inicio de instrucción, denominado auto de radicación o cabezada de proceso), estaba, antes de la reforma constitucional, obligado a presentar los medios probatorios que demostrasen plenamente que estaban acreditados los elementos del cuerpo del delito (esto es, el tipo penal) y la responsabilidad del imputado. Obviamente, tal exigencia reñía con el sentido de la presunción de inocencia, dado que, la responsabilidad penal del imputado no se puede establecer por actos de investigación, menos aún realizados en sede pre-jurisdiccional; por el contrario, y vinculado con el derecho constitucional a un juicio previo, requiere la realización de un juzgamiento ante el órgano jurisdiccional, donde por la práctica de la prueba, regida por los principios de oralidad, inmediación, contradicción y publicidad, se pueda establecer que ha quedado desvirtuada la presunción de inocencia. Frente a ello, la reforma constitucional, en concreto al artículo 160,22 establece que solamente el representante del Ministerio Público debe contar con indicios que a él le cause convicción de la presencia de un hecho delictivo y la presunta responsabilidad del imputado, y sobre la base de esa convicción ejercer la acción penal y solicitar el dictado de medidas coercitivas (como por ejemplo, la orden de aprehensión), a fin que tenga conocimiento el órgano jurisdiccional y posibilitar el inicio del respectivo proceso penal.

(2) Antes el imputado sólo podía ofrecer como testigos a favor a aquellos presentes en el momento que se produjeron los hechos. Aquí también se ve un debilitamiento tanto a la presunción de inocencia del imputado como al ejercicio de su derecho de defensa, al limitársele sus órganos de prueba a los denominados: testigos presenciales, no permitiéndosele presentar otro tipo de testigos (como los referenciales o de oídas, válidos en la mayoría de sistemas de justicia penal). Sin embargo, a raíz de la reforma constitucional al artículo 20, literal B), Fracción IV), ${ }^{23}$ se ha eliminado la exi-

respetar, en la órbita de sus facultades, dichas garantías y las prerrogativas que esta Constitución Local concede".

Artículo 210 de la Constitución Política del Estado de Zacatecas: "En el Estado de Zacatecas todo individuo gozará de las garantías que otorga la Constitución Política de los Estados Unidos M exicanos, así como de los derechos establecidos por la Constitución Política del Estado y las leyes que de ellas emanen, cuya vigencia no podrá suspenderse ni restringirse sino en los casos y mediante los procedimientos que los respectivos ordenamientos determinen".

22 Artículo 16. "Nadie puede ser molestado en su persona, familia, domicilio, papeles o posesiones, sino en virtud de mandamiento escrito de la autoridad competente, que funde y motive la causa legal del procedimiento.

No podrá librarse orden de aprehensión sino por la autoridad judicial y sin que preceda denuncia o querella de un hecho que la ley señale como delito, sancionado con pena privativa de libertad y obren datos que establezcan que se ha cometido ese hecho y que exista la probabilidad de que el indiciado lo cometió o participó en su comisión. (....)".

23 El reformado artículo 20 은 constitucional, literal b), Fracción IV) señala que el imputado tiene derecho a 
gencia que las personas cuyo testimonio se solicite deben haber estado en el lugar de los hechos. Esta eliminación es correcta, porque, como se indicó, el testigo no solamente es aquel que ha visto o percibido por sus sentidos los hechos materia de proceso, sino también el que ha tenido conocimiento del mismo a pesar que no lo ha presencia; es el caso del testigo de oídas o referencial.

(3) El anterior artículo 20으, literal b), fracción VIII) de la Constitución Política de los Estados Unidos Mexicanos permitía que el imputado se defendiese a través de una "persona de confianza", que con frecuencia era un "coyote" o litigante sin licencia, que propiciaba la comupción. A hora, con la reforma constitucional el imputado tiene derecho a una defensa adecuada por abogado, al cual elegirá libremente incluso desde el momento de su detención; ${ }^{24}$ mejorándose, de esta manera, la calidad de la defensa técnica que a la postre guarda relación con el derecho a la presunción de inocencia.

Por otro lado, y en lo que respecta al Perú, en sus dos últimas constituciones se ha mencionado el derecho a la presunción de inocencia. ${ }^{25}$

En ese sentido, el artículo 2ㅜㅡ, inciso 20), letra F) de la Constitución Política del Perú de 1979, establecía que: "Toda persona es considerada inocente mientras no se haya declarado judicialmente su responsabilidad". Idéntico texto lo encontramos en la vigente Constitución de 1993, en su artículo 2으, inciso 24, letra E).

A simismo, el Perú se encuentra vinculado al respeto de la presunción de inocencia a raíz de los instrumentos internacionales que ha suscrito, como por ejemplo la Convención A mericana, que en su artículo 8o, inciso 2) establece que: «Toda persona inculpada de delito tiene derecho a que se presuma su inocencia mientras no se establezca legalmente su culpabilidad». ${ }^{26}$ Por otro lado, y aunque se verá en el último punto del presente estudio, la Corte Interamericana de Derechos Humanos ha precisado que «el principio de la presunción de inocencia, tal y como se desprende del artículo 8.2 de la Convención, exige que una persona no pueda ser condenada mien-

que se le reciban los testigos y demás pruebas pertinentes que ofrezca, concediéndosele el tiempo que la ley estime necesario al efecto y auxiliándosele para obtener la comparecencia de las personas cuyo testimonio solicite, en los términos que señale la ley, se está refiriendo al derecho de probar.

24 Según el reformado artículo 20 o constitucional, literal b), fracción VIII), el imputado tiene derecho a una defensa adecuada por abogado, al cual elegirá libremente incluso desde el momento de su detención. Si no quiere o no puede nombrar un abogado, después de haber sido requerido para hacerlo, el juez le designará un defensor público. También tendrá derecho a que su defensor comparezca en todos los actos del proceso y éste tendrá obligación de hacerlo cuantas veces se le requiera.

25 Esta figura no se encontraba regulada en la Constitución de 1933.

26 Según la Comisión Interamericana de Derechos Humanos, la presunción de inocencia significa que nadie puede ser condenado por un delito "mientras que no se establezca plenamente su culpabilidad...". El Comité de Derechos Humanos de la ONU, al comentar el Art. 14 del "Pacto Internacional de Derechos Civiles y Políticos", observó que "en virtud de la presunción de inocencia, la carga de la prueba recae sobre la acusación, y el acusado tiene el derecho de la duda". No puede suponerse a nadie culpable a menos que se haya demostrado la acusación fuera de toda duda razonable -dice un comentario del Comité-. 
tras no exista prueba plena de su responsabilidad penal. Si obra contra ella prueba incompleta o insuficiente, no es procedente condenarla, sino absolverla».

Como se puede apreciar, el derecho a la presunción de inocencia tuvo una mayor tradición legislativa en Perú que en México. Asimismo, tampoco en el Perú se ha presentado la coexistencia de una Constitución Federal con las de las entidades federativas, que sí está presente en México.

A demás, el Perú, por presentar una data legislativa mayor que México, los códigos de procedimientos penales que han estado vigentes durante las constituciones de 1979 y 1993, han regulado el derecho a la presunción de inocencia. ${ }^{27}$ México recién está en un procedo de adecuación de los códigos de procedimientos penales de las entidades federativas al nuevo marco constitucional, producto de la reforma del 19 de Junio del 2008.

Sin embargo, en la actualidad, en ambos países y por imperio Constitucional, toda persona debe ser considerada inocente desde el primer momento que ingresa al foco de atención de las normas procesales, debiendo conservar su estado natural de libertad, con algunas restricciones propias de la investigación, hasta que mediante una sentencia se declare su culpabilidad.

\subsection{El tratamiento jurisprudencial del derecho a la presunción de inocencia}

En lo que respecta a M éxico, se indicó que, a pesar que la recepción legislativa del derecho a la presunción de inocencia es reciente, ello no ha sido impedimento alguno para que él mismo presente un desarrollo jurisprudencial.

Sin embargo, antes de ingresar al tratamiento jurisprudencial dispensado a esta figura en M éxico, es menester establecer que, en aquel país, el más alto órgano jurisdiccional es la Suprema Corte de Justicia de la Nación, la cual, si bien desempeña sus funciones en el fuero federal, sus decisiones también son consultadas y aplicadas por los órganos jurisdiccionales de cada entidad federativa.

Asimismo, las decisiones que emite la Suprema Corte se clasifican en dos: a) tesis aislada y, b) jurisprudencia; siendo esta última la que detenta carácter vinculante; es decir, el de ser un precedente de obligatoria observancia, hasta que, se interrumpa su vigencia o sea modificada por una nueva; en ambos caso, por la Suprema Corte.

A hora bien, en el caso de la presunción de inocencia, la Suprema Corte, a lo largo de su historia, solamente ha emitido tres jurisprudencias, las cuales son: ${ }^{28}$

27 Nos estamos refiriendo al Código Procesal Penal de 1991, así como el del 2004.

28 Asimismo, se cuenta con 21 tesis aisladas. 
“Si bien es cierto que el principio de presunción de inocencia implica que no puede sancionarse a una persona hasta en tanto se desahoguen las pruebas conducentes que demuestren su culpabilidad, también lo es que no opera tratándose del aseguramiento momentáneo a que se refiere el artículo 55 de la Ley de Cultura Cívica del Distrito Federal, en términos del cual el policía en servicio debe detener y presentar a la persona ante el Juez cuando sea informado de la comisión de una infracción inmediatamente después de que hubiese sido realizada o se encuentre en poder del presunto infractor el objeto $o$ instrumento, huellas o indicios que hagan presumir fundadamente su participación en la infracción, siendo hasta el inicio del procedimiento correspondiente cuando surge el deber de respetar el principio señalado, ya que antes sólo se está frente a un acto policial que atiende a una necesidad y urgencia, pero que no se traduce en una declaratoria de culpabilidad del probable infractor. Además, conforme al artículo 55 aludido, el policía en servicio debe detener y presentar al probable infractor inmediatamente ante la autoridad competente, de tal suerte que la detención no queda al solo arbitrio del policía, pues se exige que esté en servicio y que se actualicen los supuestos de la norma para que proceda el aseguramiento como medida preventiva" ${ }^{29}$

Como se puede apreciar esta jurisprudencia, en cierta forma, aborda la relación entre el derecho a la presunción de inocencia y la detención policial. En ese orden de ideas, resuelve el dilema amparándose al acto policial que atiende a una necesidad y urgencia, pero que no se traduce en una declaratoria de culpabilidad del probable infractor. Por otro lado, las razones de necesidad y urgencia no son otras que las situaciones de flagrancia delictiva, la orden judicial de aprehensión o bien la orden del Ministerio Público sometida, posteriormente, a un juicio de convalidación por parte del juzgador.

"La circunstancia de que determinados principios como los de debido proceso legal y presunción de inocencia no sólo estén consagrados en la Constitución Federal, sino también en tratados internacionales, no significa que no pueda justificarse una sentencia de condena o que todo acto de autoridad que afecte los intereses del procesado, como su libertad, trastoquen dichos principios. Por el contrario, lo que en ellos se establece es la condicionante de que dicha afectación al quejoso, en su caso, se vea justificada por la constatación de haberse observado o cumplido los requisitos que la propia ley contempla para que esa afectación quede enmarcada dentro de la legalidad en aras del interés público que es inherente al proceso penal y, en general, a la persecución de los delitos. Luego, si se obtiene que el sentido del fallo se justifica por haberse cumplido los requisitos legales exigidos por el caso y con base en la normatividad aplicable, resulta obvio que no se transgreden los principios aludidos y consagrados en la Constitución ni, por ende, los posibles tratados que igualmente los reconocieran". ${ }^{30}$

\footnotetext{
29 Acción de inconstitucionalidad 21/2004. Diputados integrantes de la Tercera Legislatura de la Asamblea Legislativa del Distrito Federal. 26 de abril de 2007. Mayoría de nueve votos. Ausente: José de Jesús Gudiño Pelayo. Disidente: José Ramón Cossío Díaz. Ponente: Margarita Beatriz Luna Ramos. Secretaria: Claudia Mendoza Polanco.

El Tribunal Pleno, el quince de octubre en curso, aprobó, con el número 112/2007, la tesis jurisprudencial que antecede. México, Distrito Federal, a quince de octubre de dos mil siete.

30 Jurisprudencia emitida en virtud de los siguientes amparos:
} 
En esta jurisprudencia, la Suprema Corte ha establecido la importancia del contenido y motivación de una sentencia condenatoria, la cual, si observa lo estipulado en las normas legales, no se vería afectado el derecho a la presunción de inocencia. Sin embargo, también es de resaltar que se menciona la entonces falta de regulación constitucional de esta figura, pero que, ello no impide su reconocimiento en el sistema jurídico mexicano en virtud a los instrumentos internacionales que el país del norte ha suscrito.

"Si del conjunto de circunstancias y pruebas habidas en la causa penal se desprenden firmes imputaciones y elementos de cargo bastantes para desvirtuar la presunción de inocencia que en favor de todo inculpado se deduce de la interpretación armónica de los artículos 14, párrafo segundo, 16, párrafo primero, 19, párrafo primero, 21, párrafo primero y 102, apartado A, párrafo segundo, de la Constitución Política de los Estados Unidos M exicanos, y por otro lado, el encausado rechaza las imputaciones y niega el delito, o su participación culpable en su actualización, éste necesariamente debe probar los hechos positivos en que descansa su postura excluyente, sin que baste su sola negativa, no corroborada con elementos de convicción eficaces, pues admitir como válida y por sí misma suficiente la manifestación unilateral del inculpado, sería destruir todo el mecanismo de la prueba circunstancial y desconocer su eficacia y alcance demostrativo". ${ }^{31}$

En esta interesante jurisprudencia se ha establecido que el imputado no podrá cuestionar un fallo condenatorio como contraviniente a la presunción de inocencia, cuando ha existido pruebas de cargo y el imputado y su abogado defensor no han aportado elementos probatorios que las enerven. Ello es importante, porque, como estrategia, la defensa no puede detentar un rol pasivo durante el juzgamiento, dejando que el M inis-

Amparo directo 470/2004. 21 de enero de 2005. Unanimidad de votos. Ponente: José Nieves Luna Castro. Secretario: Jorge Hernández Ortega.

Amparo directo 283/2005. 8 de septiembre de 2005. Unanimidad de votos. Ponente: Adalid Ambriz Landa. Secretario: Omar Fuentes Cerdán.

Amparo directo 566/2005. 24 de noviembre de 2005. Unanimidad de votos. Ponente: Adalid Ambriz Landa. Secretario: Roberto Antonio Domínguez Muñoz.

Amparo directo 612/2005. 17 de marzo de 2006. Unanimidad de votos. Ponente: José Nieves Luna Castro. Secretario: Jorge Hernández Ortega.

A mparo directo 9/2006. 17 de marzo de 2006. Unanimidad de votos. Ponente: Adalid Ambriz Landa. Secretario: Omar Fuentes Cerdán.

31 Jurisprudencia emitida en virtud de los siguientes amparos:

A mparo directo 533/2004. 7 de marzo de 2005. Unanimidad de votos. Ponente: Óscar Javier Sánchez Martínez. Secretario: Enedino Sánchez Zepeda.

Amparo directo 526/2004. 18 de abril de 2005. Unanimidad de votos. Ponente: Evaristo Coria Martínez. Secretario: Rolando Fimbres Molina.

A mparo directo 567/2004. 16 de mayo de 2005. Unanimidad de votos. Ponente: Óscar Javier Sánchez Martínez. Secretario: Hugo Reyes Rodríguez.

Amparo directo 168/2005. 16 de mayo de 2005. Unanimidad de votos. Ponente: Óscar Javier Sánchez Martínez. Secretaria: Francisca Célida García Peralta.

Amparo directo 531/2004. 6 de junio de 2005. Unanimidad de votos. Ponente: Óscar Javier Sánchez Martínez. Secretario: Hugo Reyes Rodríguez. 
terio Público sea la única parte quien ofrezca y desahoguen sus pruebas, so pretexto que no necesita hacer nada por imperio de la presunción de inocencia.

Por otro lado, también en el Perú se ha dado un tratamiento jurisprudencial a la presunción de inocencia, ya sea por los órganos que constituyen el Poder Judicial, así como por el Tribunal Constitucional.

Asimismo, las decisiones jurisprudenciales son vinculantes en el Perú cuando son emitidas por las salas penales de la Corte Suprema, así como, por el Tribunal Constitucional, siempre y cuando, expresamente se indique tal condición.

Frente a ello, nos vamos a referir al Tribunal Constitucional, quien en el Perú es el supremo intérprete de la Constitución. En ese orden de ideas, la presunción de inocencia es:

a) Un derecho fundamental y una presunción iuris tantum. El derecho fundamental a la presunción de inocencia, en tanto que presunción iuris tantum, implica que a todo procesado se le considera inocente mientras no se pruebe su culpabilidad: vale decir, hasta que no se exhiba prueba en contrario. Rige desde el momento en que se imputa a alguien la comisión de un delito, quedando el acusado en condición de sospechoso durante toda la tramitación del proceso, hasta que se expida la sentencia definitiva. ${ }^{32}$

Al respecto, como se indicó en otro lugar, el proceso penal es el marco para la discusión (mejor, transformación) de un conflicto de intereses generado por la comisión de un ilícito penal, donde los actores (a excepción del imparcial Juez) tienen sus propios objetivos, expectativas de las resultas del proceso penal, que, por lo general, se contrapone a los de su contraparte. Sin embargo, la discusión del conflicto penal no puede realizarse sin la observancia de principios y garantías, que son irrevocables; entre ellos, la presunción de inocencia.

En esa línea, el proceso no es como liberalmente se concibió mero instrumento de aplicación de la ley para la decisión de un litigio sino esencial e indispensable articulación de imperativos jurídico-fundamentales, condicionantes y determinantes del desarrollo de la potestad jurisdiccional y de la satisfacción del derecho a la tutela judicial efectiva. ${ }^{33}$

Y uno de esos imperativos es que la expectativa de sanción no se materialice a expensas de cualquier persona. La imputación de cargos penales sólo debe ser expresión del interés de justicia que busca la víctima y que lo hace suyo el Ministerio Público, judicializándolo como expectativa de sanción, pero que, per se, no constituye una declaración de culpabilidad en contra del imputado.

STC 0618-2005-PHC/TC, FF.JJ. 21 y 22.

33 Pedraz Penalva, Ernesto, (1995): “El proceso y sus alternativas” (Cuadernos de Derecho Judicial, № 27, Poder Judicial, Madrid), p. 12. 
Este imperativo, como señala el Tribunal Constitucional, es un derecho fundamental que adquiere una dimensión procedimental, en la medida que debe ser respetado en el proceso judicial, siendo éste ilegítimo e inconstitucional si no lo respeta en su desarrollo o lo vulnera en sus conclusiones, lo que debe afirmarse de modo especial en el procedimiento penal, ya que en él actúa el poder del Estado en la forma más extrema en la defensa social frente al crimen, a través de la pena, produciendo una profunda injerencia en uno de los derechos más preciados de la persona, su libertad personal. ${ }^{34}$

b) Puede ser desvirtuada en función a la actividad probatoria en el marco de un proceso penal. La presunción de inocencia se mantiene 'viva' en el proceso penal siempre que no exista una sentencia judicial que, como corolario del cauce investigatorio llevado a cabo con las garantías inherentes al debido proceso, logre desvirtuarla. ${ }^{35}$

Comprende el principio de libre valoración de la prueba en el proceso penal que corresponde actuar a los Jueces y Tribunales; que la sentencia condenatoria se fundamente en auténticos hechos de prueba, y que la actividad probatoria sea suficiente para generar en el Tribunal la evidencia de la existencia no sólo del hecho punible, sino también la responsabilidad penal que en él tuvo el acusado y así desvirtuar la presunción. ${ }^{36}$

Al respecto, en la Declaración de Derechos del Hombre y del Ciudadano de 1789, en su artículo 9, que positiva la presunción de inocencia «Tout homme étant innocent jusqu'a ce qu'il ait été declaré ocupable» (A todo hombre se le presume inocente mientras no haya sido declarado culpable), denotaba la necesidad de la actividad probatoria tendiente a demostrar la comisión de un delito, así como la responsabilidad del imputado.

Para, Sentís M elendo, la palabra prueba deriva del término latin probatio o probationis, que a su vez procede del vocablo probus que significa: bueno, por tanto lo que resulta probado es bueno y se ajusta a la realidad; de lo que se infiere, que probar consiste en verificar o demostrar la autenticidad de una cosa. ${ }^{37}$

Sin embargo, en modelos no acusatorios se tiende a llamar prueba a aquella actividad que constituyen solamente actos de investigación (como los que realizan tanto la Policía como la Fiscalía), los cuales tienen un valor meramente informativo y preparatorio del escenario del juicio oral. En efecto, en el modelo acusatorio, la investigación implica la transformación de ésta en una etapa puramente preparatoria del juicio criminal, entregada a los Fiscales, quienes deberán contar con el auxilio de la policía, conducir la investigación de los delitos, realizar las diligencias de investigación y ejercer la acción penal pública, cuando ello proceda. ${ }^{38}$

4 Nogueira Alcalá, Humberto. Ob. cit., p. 221.

35 STC 2915-2004-PHC/TC, FJ 12.

36 STC 0618-2005-PHC/TC, FJ 22.

37 Sentís Melendo, Santiago (1973): “Qué es la prueba. Naturaleza de la prueba” (Revista Derecho Procesal Iberoamericana, № 2-3, Madrid), pp. 259-260.

38 BaYtelman, Andrés / DuCE, Mauricio (2005): Litigación penal, juicio oral y prueba (Fondo de Cultura Económica, México D.F.), p. 40. 
Pese a esta información, aún vemos en nuestros operadores jurídicos la enervación de la presunción de inocencia con la compulsión de los actos de investigación, afectándose el contenido de esta garantía constitucional. En ese sentido, debe ser clara la distinción entre actos de investigación con los de prueba, la misma que se traduce de la siguiente forma:

1. Los actos de investigación buscan indagar la existencia de hechos; en cambio los actos de prueba tienen como objeto acreditar afirmaciones.

2. Los actos de investigación se realizan antes del juicio oral; en cambio, los actos de prueba tienen como escenario de realización y valoración la fase de juzgamiento, salvo las excepciones de prueba anticipada y prueba pre-constituida.

3. Los actos de investigación se rigen bajo el principio de libertad indagadora (objetiva y científica); en cambio, los actos de prueba se rigen bajo el principio de contradicción.

4. Los actos de investigación sustentan las decisiones del Fiscal (si formula acusación o requiere el sobreseimiento); en cambio, los actos de prueba sustentan las decisiones del Juez (condena o absolución).

Frente a ello, en el modelo acusatorio debemos distinguir la suficiencia de investigación y la suficiencia probatoria, esta última es la que se requiere para desvirtuar la presunción de inocencia. En otras palabras, de las resultas del juicio oral se puede obtener la declaración de culpabilidad o dejar incólume la presunción de inocencia.

El juicio oral, por tanto, en un modelo acusatorio admite como prueba todo medio apto para producir fe, con tal que cumpla con los requisitos generales de la prueba (pertinencia, relevancia, licitud, etc.), teniendo el juzgador libertad para la respectiva valoración probatoria (por lo que, lo que antes eran cuestiones de admisibilidad -ejemplo la parcialidad del testigo- ahora se tornan en cuestiones de credibilidad), cristalizados en la fundamentación (idónea y adecuada) de la sentencia.

c) Su carácter de relativo justifica la imposición de medidas cautelares personales al imputado. El derecho fundamental a la presunción de inocencia no es un derecho absoluto sino relativo. De ahí que, en nuestro ordenamiento, se admitan determinadas medidas cautelares personales -como la detención preventiva o detención provisional-, sin que ello signifique su afectación, porque tales medidas sirven precisamente para esclarecer el hecho reprochado y por ello son imprescindibles para llevar a cabo un procedimiento penal orientado en principios propios de un Estado de derecho; siempre, claro está, que tales medidas sean dictadas bajo criterios de razonabilidad y proporcionalidad. Parte de esa relatividad del derecho a la presunción de inocencia se vincula también con que dicho derecho incorpora una presunción iuris tantum y no una presunción absoluta; de lo cual se deriva, como lógica consecuencia, que la presunción de inocencia puede ser desvirtuada o destruida mediante una mínima actividad probatoria. ${ }^{39}$

39 STC 10107-2005-PHC/TC, FJ 07. 
Al respecto, considero que el camino de análisis más adecuado no es aquel que pretende justificar las medidas cautelares personales, sino en que la presunción de inocencia establece una regla de tratamiento del imputado durante el proceso penal, que obliga a reducir al mínimo estrictamente necesario las medidas restrictivas del imputado en el proceso. ${ }^{40}$ La presunción de inocencia no es incompatible con la aplicación de medidas cautelares adoptadas por el órgano competente y fundadas en derecho, basadas en un juicio de razonabilidad acerca de la finalidad perseguida y las circunstancias del caso concurrentes, como asimismo aplicando los principios la adecuación y proporcionalidad de ellas.

Sin embargo, una de las situaciones que afecta con mayor frecuencia la presunción de inocencia es la prolongación excesiva de la detención preventiva. Al respecto, la Corte Interamericana de Derechos Humanos ha señalado que esta situación, además de lesionar el derecho a la libertad personal, transgrede también el derecho a la presunción de inocencia, del cual goza toda persona que se encuentre involucrada en un proceso de investigación penal. ${ }^{41}$

En efecto, la prolongación de la prisión preventiva, con su consecuencia natural de sospecha indefinida y continua sobre un individuo, constituye una violación del principio de presunción de inocencia reconocido por el artículo 8.2 de la Convención Americana. Cabe precisar, sin embargo, que la existencia de un ambiente de creciente sospecha contra una persona en el curso del proceso criminal no es «per se» contraria al principio de presunción de inocencia. Tampoco lo es el hecho que esta sospecha creciente justifique la adopción de medidas cautelares, como la prisión preventiva, sobre la persona del sospechoso. El artículo 8.2 obliga a los Estados a recopilar el material incriminatorio en contra del acusado de un cargo criminal, con el propósito de «establecer su culpabilidad». El establecimiento de la culpabilidad implica la formulación de un juicio de reproche en una sentencia definitiva o de término. Si el Estado no determina el juicio de reproche dentro de un plazo razonable y justifica la prolongación de la privación de libertad del acusado sobre la base de la sospecha que existe en su contra, está, fundamentalmente, sustituyendo la pena con la prisión preventiva. De este modo la detención preventiva pierde su propósito instrumental de servir a los intereses de una buena administración de justicia, y de medio se transforma en fin.

d) Su relación con el in dubio pro reo. El principio In dubio pro reo no es un derecho subjetivo, sino un principio de jerarquía constitucional cuyo fin es garantizar el cabal respeto del derecho fundamental a la libertad individual, bien para resguardar

40 Montañés Pardo, Miguel Ángel (1999): La presunción de inocencia. Análisis doctrinal y jurisprudencial (A ranzadi, Pamplona), p. 41.

41 La Corte Interamericana de Derechos Humanos ha determinado que «se incurriría en una violación de la Convención al privar de libertad, por un plazo desproporcionado, a personas cuya responsabilidad criminal no ha sido establecida. Equivaldría a anticipar la pena, lo cual contraviene los principios generales del derecho universalmente reconocidos». Corte Interamericana de Derechos Humanos. Sentencia caso Tibi vs. Ecuador, 7 de septiembre de 2004, párrafo 180; Caso Suárez Rosero, párrafo 77. 
su plena vigencia, bien para restringirlo de la forma menos gravosa posible, en el correcto entendido de que tal restricción es siempre la excepción y nunca la regla. ${ }^{42}$

En ese sentido, el citado principio es aplicable al emitir pronunciamiento de fondo terminal, sobre la responsabilidad o irresponsabilidad penal del procesado, que incidirá inevitablemente en su libertad individual, dado que en etapas anteriores a la sentencia se encuentra vigente la presunción de inocencia, que es garantía del debido proceso reconocido por la Norma Suprema.

A mbos principios se encuentran reconocidos por nuestra Constitución Política, en tanto que los límites entre ambos radican en que el in dubio pro reo tiene presencia cuando surge una duda que afecte el fondo del proceso; y la presunción de inocencia está presente durante todas las fases del proceso penal así como en todas sus respectivas instancias, siendo un principio reconocido a nivel internacional y garantía fundamental, por la que se cree inocente al procesado en tanto no exista un medio de prueba evidente que demuestre lo contrario y el In dubio pro reo opera como mecanismo de valoración probatoria, dado que en los casos donde se presente la duda razonable, deberá absolverse al procesado. ${ }^{43}$

Sin embargo, a pesar de to do este marco y desarrollo jurisprudencial, en el Perú se han dado casos que, desde nuestro punto de vista, se ha violado la presunción de inocencia.

Por ejemplo, mediante Resolución № 072-2008-PCNM, de fecha 14 de mayo de 2008, el Consejo Nacional de la Magistratura (CNM), ${ }^{44}$ declaró la destitución ${ }^{45}$ del doctor Walter Ronald Medina Llamosa, del cargo de Fiscal Adjunto Provincial Titular Mixto de Maynas del Distrito Judicial de Loreto, debido, según los considerandos de

42 STC 1994-2002-PHC/TC

43 Romero Felipa, Ana María. "Los principios constitucionales de in dubio pro reo y presunción de inocencia", en: Estafeta Jurídica Virtual, disponible en: www.amag.edu.pe [03/08/08].

44 Es un Organismo Autónomo e independiente de los demás órganos constitucionales y Poderes del Estado. Se encuentra sometido únicamente a la Constitución Política del Perú y a su propia Ley Orgánica (L.O № 26397). AI CNM le compete seleccionar, nombrar, ratificar y destituir a los jueces y fiscales del Perú en todos los niveles y jerarquías, con excepción de los jueces que han sido elegidos por elección popular. Asimismo, el CNM nombra, ratifica y/o destituye al Jefe de la Oficina Nacional de Procesos Electorales (ONPE) y al Jefe del Registro Nacional de Identificación y Estado Civil (RENIEC).

45 El CNM, previo proceso disciplinario, aplica la sanción de destitución a Vocales y Fiscales Supremos. Para ello, de oficio o ante denuncia de parte, puede abrirles investigación preliminar y proceso disciplinario; y en el caso de jueces y fiscales de inferior jerarquía a los supremos (como es el caso que estamos comentando), la investigación preliminar y el consiguiente proceso disciplinario se hace a solicitud de la Corte Suprema o de la Junta de Fiscales Supremos, según sea el caso.

La destitución de un juez o fiscal de cualquier nivel se produce previa audiencia con el interesado y cuando éste ha sufrido sentencia penal o cometido actos no acordes con la conducta funcional que un magistrado debe observar, los mismos que sin ser delito, atentan contra los deberes de su función, el decoro y la dignidad del cargo que se le ha conferido.

Así también, el CNM, por haberles nombrado, puede destituir al Jefe de la O ficina Nacional de Procesos Electorales ONPE y al Jefe del Registro Nacional de Identidad y Estado Civil, RENIEC. 
la citada resolución, al haber incurrido en inconducta deshonrosa al haber sido denunciado y encontrarse comprendido en un proceso penal por la presunta comisión del delito contra la libertad sexual-en agravio de la menor de iniciales M.G.R.S, lo cual fue difundido con caracteres de escándalo en los diversos medios de comunicación social mellando la imagen del M inisterio Público ante la sociedad, y si bien es cierto la denuncia y el proceso penal contra el Fiscal M edina Llamosa, así como su difusión ante los distintos medios de comunicación social fueron realizadas por dicha menor, esto no enerva la responsabilidad de dicho Fiscal, puesto que la denuncia y su difusión devino a consecuencia de la relación indebida que estableció con la citada menor, habiendo incurrido, por lo tanto, con dicha conducta en la causal prevista por el artículo 23 incisos a) ${ }^{46}$ y g ${ }^{47}$ del actual Reglamento de Organización y Funciones de la Fiscalía Suprema de Control Interno del Ministerio Público, por lo que es pasible de la sanción de destitución al haber incurrido en la comisión de un hecho grave que atenta contra la respetabilidad del M inisterio Público, compromete la dignidad del cargo y lo desmerece en el concepto público, por lo que es pasible de la sanción de destitución de conformidad con lo dispuesto en el artículo 31 numeral 2 de la Ley $N^{\circ} 26397$, Ley Orgánica del Consejo Nacional de la M agistratura. ${ }^{48}$

De la citada resolución se aprecia que, la destitución del mencionado doctor se debió a una serie de irregularidades incurridas por el mismo junto con una menor de edad; sin embargo, también hace mención el haber sido denunciado y encontrarse comprendido en un proceso penal por la presunta comisión del delito contra la libertad sexual, en agravio de la menor de iniciales M .G.R.S. Ello, nos impulsa a preguntarnos si se le afectó o no la garantía constitucional de la presunción de inocencia, máxime si uno de los argumentos de la destitución sería el estar siendo procesado por la presunta comisión del delito de violación sexual en agravio de menor de dieciocho años.

Frente a ello, y descrito el tratamiento dado a la presunción de inocencia en el Perú, considero que el Consejo Nacional de la Magistratura, en el caso de Walter Ronald M edina Llamosa, debió de haberla observado; o por lo menos, en la resolución emitida por este órgano y señalado en el ítem 3.1 del presente estudio, no debió de mencionar el hecho que estaba siendo procesado por el delito de violación sexual en agravio de menor, ni mencionar hechos relacionados a la imputación penal, ${ }^{49}$ hasta la existencia de una declaración de culpabilidad, en mérito de actividad probatoria realizada en seno de juicio oral; ello, de acuerdo con la jurisprudencia anteriormente citada. M ás vale pecar en ser estrictos en la aplicación de esta garantía constitucional, que ligeros, dado que, si perseguimos apartándonos de la ley, si se da el caso que a nosotros se nos persigan, quién saldrá en nuestro auxilio.

46 "A) Hecho grave que sin ser delito compromete la dignidad del cargo y los desmerezca en el concepto público".

47 "G) Incumplimiento de las disposiciones regales, normas reglamentarias y de carácter interno emitidas por la Fiscalía de la Nación o el Órgano de Gobierno del Ministerio Público y por sus superiores jerárquicos".

48 Considerando Trigésimo Sexto. El resaltado es nuestro.

49 No nos referimos al hecho de haber llevado a una diligencia de pesaje de droga a una persona extraña a la misma. 


\subsection{La presunción de inocencia y su relación con otros derechos constitucionales}

La Segunda Sala de la Suprema Corte de Justicia de la Nación (M éxico), en el A mparo en revisión № 89/2007, ha establecido lo siguiente: “El principio de presunción de inocencia que en materia procesal penal impone la obligación de arrojar la carga de la prueba al acusador, es un derecho fundamental que la Constitución Política de los Estados Unidos M exicanos reconoce y garantiza en general, cuyo alcance trasciende la órbita del debido proceso, pues con su aplicación se garantiza la protección de otros derechos fundamentales como son la dignidad humana, la libertad, la honra y el buen nombre, que podrían resultar vulnerados por actuaciones penales o disciplinarias irregulares. En consecuencia, este principio opera también en las situaciones extraprocesales y constituye el derecho a recibir la consideración y el trato de «no autor o no partícipe» en un hecho de carácter delictivo o en otro tipo de infracciones mientras no se demuestre la culpabilidad; por ende, otorga el derecho a que no se apliquen las consecuencias a los efectos jurídicos privativos vinculados a tales hechos, en cualquier materia". ${ }^{50}$

En ese orden de ideas, se puede inferir la relación que guarda el derecho a la presunción de inocencia con otros derechos constitucionales; por lo que, en este punto pasaremos revista a la referida relación, específicamente con los derechos constitucionales: a la libertad personal, al honor, a la propiedad y a un juicio previo.

\section{A. La presunción de inocencia y su relación con el derecho a la libertad personal}

Como se indicó en los puntos anteriores, la presunción de inocencia exige que, cualquier medio de afectación a los derechos constitucionales del imputado deber ser empleados como ultima ratio, esto es, en forma excepcional, proporcional y razonable.

Esta garantía tiene una proyección mayor en la protección de la libertad personal (piénsese, por ejemplo, en el dictado de una prisión preventiva, ${ }^{51}$ y por allí debe ir el desarrollo doctrinal y jurisprudencial.

50 Amparo en revisión 89/2007. 21 de marzo de 2007. Cinco votos. Ponente: Genaro David Góngora Pimentel. Secretario: Marat Paredes Montiel.

51 La prisión preventiva suscita una sorprendente coincidencia dentro de la doctrina. Casi sin excepción toda ella reconoce que se trata de una medida cautelar resultado de un conflicto insoslayable entre los intereses colectivos tendentes a asegurar la virtualidad de la justicia penal y los intereses individuales. El sacrificio de estos últimos en favor de aquéllos excepcionando así una regla general de respeto de los derechos fundamentales de la persona recomiendan que su declaración esté revestida de un carácter de excepcionalidad, proporcionalidad, necesariedad, discrecionalidad, presunción de inocencia, etc. Sin embargo, pese a esta general coincidencia crítica, asumida también por la jurisprudencia, las posibilidades de decretar prisión provisional han ido en aumento con el transcurso del tiempo. Si en una primera etapa se vinculaba exclusivamente a las necesidades de asegurar las pruebas y/o evitar las eventuales fugas del imputado, pronto se suman nuevas razones fundadas en criterios de prevención general y especial. El «peligro de reincidencia», en Alemania y Austria, el «orden público» en Italia o 
En ese sentido, el artículo 9.1 del Pacto Internacional de Derechos Civiles y Políticos consagra el derecho a la libertad personal de la siguiente forma: " $(t)$ odo individuo tiene derecho a la libertad y a la seguridad personales. Nadie podrá ser privado de su libertad, salvo por las causas fijadas por la ley y con arreglo al procedimiento establecido en ésta".

De igual modo en el artículo 7 del Pacto de San José de Costa Rica, cuando dispone que "1. Toda persona tiene derecho a la libertad y a la seguridad personal. 2. Nadie puede ser privado de su libertad física, salvo por las causas y en las condiciones fijadas de antemano por las Constituciones Políticas de los Estados Partes o por las leyes dictadas conforme a ella. 3. Nadie puede ser sometido a detención o encarcelamiento arbitrarios". ${ }^{52}$

El Tribunal Constitucional peruano ha dicho que libertad personal, "es un derecho subjetivo, reconocido en el inciso 24) del artículo $2^{\circ}$ de la Constitución y, al mismo tiempo, uno de los valores fundamentales de nuestro Estado Constitucional de Derecho, por cuanto fundamenta diversos derechos constitucionales a la vez que justifica la propia organización constitucional. ${ }^{53}$

Como derecho subjetivo, la libertad personal "garantiza que no se afecte indebidamente la libertad física de las personas, esto es, su libertad locomotora, ya sea mediante detenciones, internamientos o condenas arbitrarias. Los alcances de la garantía dispensada a esta libertad comprenden frente a cualquier supuesto de privación de la libertad locomotora, independientemente de su origen, la autoridad o persona que le haya efectuado. Garantiza, pues, ante cualquier restricción arbitraria de la libertad per-

nuestra «alarma» $y$ «frecuencia» del delito demuestran sin ningún genero de dudas esa evolución hacia una prisión provisional entendida en un sentido preventivo y punitivo. Incluso los propios criterios empleados por el legislador para establecer sus plazos poniéndola en relación con la gravedad de la pena señalada al delito que se imputa, prueban, como apunta Gómez Colomer, la relación entre el instituto procesal y las exigencias de seguridad ciudadana.

Según Barona Vilar, la detención judicial debe concebirse como una medida cautelar personal excepcional, en el sentido de que debe hacerse uso de la misma en última instancia; por ello debe calificarse como: 1) Una privación de libertad del sujeto que la padece; 2) Una medida cautelar personal del proceso penal, con el fin de asegurar el proceso y su normal desarrollo así como la ejecución de la posible sentencia que, en su día, se dicte; 3 ) Se trata de una medida instrumental en el sentido de que sive a los fines antes señalados; 4) Se trata de una medida provisional, revisable en cualquier momento del procedimiento, de oficio o a instancia de parte; 5) Se trata de una medida excepcional, frente a la situación normal de esperar el juicio en estado de libertad. Cfr. Barona VILAR, Silvia (1987): Prisión provisional y medidas alternativas (Bosch, Barcelona), p. 28.

52 Para Eguiguren, la libertad personal "comprende una libertad física o ambulatoria, que reconoce a toda persona la facultad de desplazarse libremente, sin otras limitaciones que las impuestas por el medio en que se pretende actuar y las establecidas por las normas constitucionales para preservar otros derechos o valores igualmente relevantes". Cfr. Eguiguren Prael, Francisco (2002): Estudios constitucionales (ARA Editores, Lima), pp. 27-28.

53 Exp. 1091-2002-HC/TC, Fundamento Jurídico 1, de la parte referida a los alcances constitucionales de la libertad personal. 
sonal, según señala el artículo 9o de la Declaración Universal de Derechos Humanos y el artículo 7.3 de la Convención Americana de Derechos Humanos. ${ }^{54}$

El derecho a la libertad personal es un derecho constitucional, dado que, es una expresión de la dignidad humana y de la libertad, dispuesta normativamente, que supongan un conjunto de facultades para su titular, y que vinculen positiva y negativamente al poder político al punto de legitimar su actuación. ${ }^{55}$

Conviene precisar, que en doctrina, se sostiene que la libertad individual tiene una dimensión más amplia que la libertad personal. Así, Alzaga concibe la libertad personal como un principio que tiene su desarrollo constitucional en otros preceptos de la misma, con lo cual se amplía el contenido hasta lo que la doctrina francesa denomina libertad física, comprensiva de la libertad individual en un sentido estricto, la circulación y el derecho a la intimidad. ${ }^{56}$

Eguiguren indica que en su aspecto de libertad física, garantiza a su titular el no verse arbitraria o irrazonablemente privado de ésta, ni ser detenido o sometido a restricciones de la libertad en supuestos distintos a los previstos por la norma constitucional, la ley o los pactos internacionales sobre derechos humanos. ${ }^{57}$

Más allá de la distinción entre los conceptos de libertad individual o libertad personal, ${ }^{58}$ el contenido de este derecho está dado a la libertad física, de locomoción o ambulatoria, aspecto de la libertad que suele identificarse con la expresión libertad personal.

En otras palabras, está referida al reconocimiento que hace el ordenamiento jurídico de la capacidad de autodeterminación libre y voluntaria del ejercicio de las facultades ambulatorias o de locomoción de las personas. ${ }^{59}$

54 CAstillo Córdoba, Luis, (2004): Habeas corpus, amparo y habeas data (ARA Editores, Lima), p. 318.

55 CAstillo Córdoba, Luis, (2003): Elementos de una teoría general de los derechos constitucionales (ARA Editores, Lima), p. 37.

56 Cita tomada de CASTAÑEDA OTSU, Susana Ynes (2005): El proceso de habeas corpus en el código procesal constitucional (Introducción a los procesos constitucionales. Comentarios al Código Procesal Constitucional, Jurista Editores, Lima), p. 93.

57 Eguiguren Prael, Francisco. Ob. cit., pp. 27-28.

58 El Dr. Espinosa-Saldaña acota que el término en rigor debería ser la libertad personal, dado que, lo que se está hablando es el pleno ejercicio de la dimensión más bien física de aquel derecho y valor que se conoce con el nombre de libertad. Como es de conocimiento general, esta faceta de la libertad (entendida al mismo tiempo como autodeterminación y no interferencia) es doctrinariamente conocida con el nombre de la libertad personal. Cfr. EsPinosA-SALDAÑA BARRERA, Eloy. Habeas corpus contra resoluciones judiciales: entre la evolución del concepto "proceso regular" y la determinación del ámbito de acción del juez constitucional (Jurisdicción Constitucional, impartición de justicia y debido proceso, ARA Editores, Lima), p. 146.

59 Ello como expresión de la cláusula personalista del artículo 1ํ de la Constitución peruana y de manera más concreta como una de las manifestaciones del principio general de libertad, según el cual, nadie está obligado a hacer lo que la ley no manda, ni impedido de hacer lo que ella no prohíbe, reconocido en el literal a), inciso 24) del artículo 2o de la Constitución Política del Perú. 
A hora bien, en los sistemas jurídicos mexicano y peruano se puede afectar la libertad personal sin vaciar de contenido el derecho a la presunción de inocencia, sólo por situaciones previstas en la ley. Estas situaciones son:

(a) Por aplicación de las denominadas medidas cautelares o de coerción personales, como por ejemplo, las detenciones, la prisión preventiva, el arraigo o arresto domiciliario, el impedimento de salida del país o el internamiento en centros psiquiátricos. Sin embargo, estas medidas se aplican sólo cuando se ha configurado una situación jurídica cautelable, existan riesgos procesales y no hayan otras medidas menos lesivas para aplicar; debiendo ser proporcional la medida cautelar aplicada con la situación jurídica a cautelar. ${ }^{60}$

(b) Por ejecución de la sanción establecida en una sentencia condenatoria; sanción que puede ser el internamiento en un centro penitenciario en cumplimiento de la pena privativa de libertad, o bien, el ingreso en un centro psiquiátrico en cumplimiento de una medida de seguridad; con los respectivos descuentos de carcelería establecidos en los ordenamientos de M éxico y de Perú. ${ }^{61}$

\section{B. La presunción de inocencia y su relación con el derecho al honor}

El derecho al honor debe ser entendido, en principio, a través de su doble proyección: a) el subjetivo, el cual tiene que ver con la opinión que sobre su persona tiene el individuo, es decir, la autoestima; b) el objetivo, el mismo que gira en torno a la imagen que los demás tienen sobre uno, esto es, la buena imagen.

A hora bien, en la praxis judicial se están dando casos, algunos incluso legitimados por las normas penales, por los cuales al atentar contra la presunción de inocencia, también vulneran el derecho al honor en su doble proyección.

Por ejemplo, al presentarlos a los medios de comunicación no como presuntos, sino como certeros responsables; o bien, con una vestimenta ultrajante (ej. Traje a rayas) o dentro de jaulas (como ocurrió en el Perú, durante la década de los 90 al presentar a los presuntos terroristas a la prensa).

Frente a ello, el artículo II, numeral 2) del Código Procesal Penal peruano del 2004, ha señalado que: "Hasta antes de la sentencia firme, ningún funcionario o autoridad pública puede presentar a una persona como culpable o brindar información en tal sentido". Sin embargo, pese a esta prudente prohibición, el artículo 70 del citado cuerpo de leyes ha indicado que: "La Policía podrá informar a los medios de comunicación social acerca de la identidad de los imputados. Cuando se trate de la víctima,

60 Artículo 10 으 del Código de Procedimientos Penales del Estado de México y artículo 253ํ del Código Procesal Penal del Perú.

61 Artículo 384으 del Código de Procedimientos Penales del Estado de M éxico y artículo 490으 del Código Procesal Penal del Perú. 
testigos, o de otras personas que se encontraren o pudieren resultar vinculadas a la investigación de un hecho punible requerirá la previa autorización del Fiscal".

Al respecto, consideramos que, una interpretación sistemática de ambos artículos que no afecte los contenidos tanto de la presunción de inocencia como el honor, sería la siguiente: la policía, en el marco de sus funciones constitucionales de prevención, aseguramiento e investigación, si detiene o cita a alguna persona a sus instalaciones, tiene la obligación de informar a los medios de comunicación social de tales actividades a la sola exigencia de estos medios; $y$, con mayor razón cuando quien solicite la información sean directos familiares o personas allegadas al detenido o citado. No obstante, a la hora que la policía brinde la información debe tener en cuenta, por lo menos dos situaciones: a) que lo que brinda es una información de sus actividades, no debe atribuir o sindicar responsabilidad penal alguna; $y, b$ ) debe proteger la seguridad personal de víctimas, testigos o cualquier persona involucrada en las investigaciones penales, para ello debe actuar en conjunto con el Ministerio Público y dentro de un programa de protección de identidades.

Estos dispositivos, comentados, no aparecen en la normatividad penal mexicana, ni federal ni en las entidades federativas, salvo lo referente al programa de protección de víctimas y testigos formulado con relación a la lucha contra la delincuencia organizada.

\section{La presunción de inocencia y su relación con el derecho a la propiedad}

El derecho a la propiedad es otro derecho constitucional que puede verse afectado a raíz de medidas o sentencias dictadas a raíz del inicio y desarrollo de un proceso penal. Sin embargo, es una tendencia en los países latinoamericanos flexibilizar la protección de este derecho constitucional, en aras de la eficacia de la investigación y persecución de delitos.

Al respecto, señalaremos, como ejemplos, grupos de casos donde se ha flexibilizado el derecho a la propiedad, con una posterior afectación a la presunción de inocencia, a raíz de las actuaciones tanto del M inisterio Público como del Poder Judicial:

(1) Con relación a las denominadas medidas de búsqueda y aseguramiento de las pruebas. Estas medidas, a diferencia de las cautelares o coercitivas, buscan el material probatorio que permita al Fiscal sustentar su pretensión acusatoria. Ahora bien, este material puede encontrarse, por ejemplo, interviniendo las comunicaciones de los investigados, levantando el secreto bancario, allanando domicilios, incautando bienes privados o clausurando locales con inmovilización de bienes muebles. No obstante, como se afecta el ejercicio de los derechos constitucionales de los investigados, se requiere que el representante del Ministerio Público obtenga la respectiva autorización por parte del Juez, salvo que los hechos se encuentren en situación de flagrancia delictiva. Sin embargo, en el caso peruano, según los artículos $218^{\circ}$ numeral 2$)^{62}$ y

${ }_{62}$ Artículo 218, numeral 2): “Cuando existe peligro por la demora, la exhibición o la incautación debe 
$241^{063}$ del Código Procesal Penal, el Fiscal, sin autorización judicial ni estando los hechos en flagrancia delictiva, podrá incautar bienes privados o clausurar locales con inmovilización de los bienes muebles, con el único alegato de la urgencia o el peligro en la demora. Esta situación, para nuestro punto de vista, atenta contra el derecho de propiedad de los afectados por tales medidas, así como una puesta en peligro al derecho a la presunción de inocencia, dado que, se le permite la actuación del Fiscal so pretexto de garantizar la eficacia de sus investigaciones, instrumentalizándose los derechos constitucionales del investigado.

(2) Con referencia al proceso de pérdida o extinción de dominio ${ }^{64}$ El artículo $22^{\circ}$ de la Constitución Política Federal de los Estados Unidos M exicanos, a raíz de su reforma en junio de 2008, regula una institución novísima para el sistema jurídico-penal mexicano, el cual es el denominado proceso de extinción de dominio, el mismo que se rige por las siguientes reglas:

I. Será jurisdiccional y autónomo del de materia penal;

II. Procederá en los casos de delincuencia organizada, delitos contra la salud, secuestro, robo de vehículos y trata de personas, respecto de los bienes siguientes:

a) Aquellos que sean instrumento, objeto o producto del delito, aun cuando no se haya dictado la sentencia que determine la responsabilidad penal, pero existan elementos suficientes para determinar que el hecho ilícito sucedió.

b) Aquellos que no sean instrumento, objeto o producto del delito, pero que hayan sido utilizados o destinados a ocultar o mezclar bienes producto del delito, siempre y cuando se reúnan los extremos del inciso anterior.

c) Aquellos que estén siendo utilizados para la comisión de delitos por un tercero, si su dueño tuvo conocimiento de ello y no lo notificó a la autoridad o hizo algo para impedirlo.

d) Aquellos que estén intitulados a nombre de terceros, pero existan suficientes elementos para determinar que son producto de delitos patrimoniales o de delincuencia organizada, y el acusado por estos delitos se comporte como dueño.

III. Toda persona que se considere afectada podrá interponer los recursos respectivos para demostrar la procedencia lícita de los bienes y su actuación de buena fe, así como que estaba impedida para conocer la utilización ilícita de sus bienes.

Del último párrafo se advierte una oculta inversión de la carga de la prueba; es decir, que ahora corresponde al afectado demostrar que los bienes de su propiedad

disponerla el Fiscal. En todos estos casos, el Fiscal una vez que tomó conocimiento de la medida o dispuso su ejecución, requerirá al Juez de la Investigación Preparatoria la correspondiente resolución confirmatoria".

63 Artículo 241: “El Fiscal podrá ordenar y ejecutar, por razones de urgencia o peligro por la demora, la clausura o vigilancia del local o la inmovilización de los bienes muebles, cuando sea indispensable para iniciar o continuar la investigación. Efectuada la medida, antes de vencidas las veinticuatro horas de realizada la diligencia, solicitará al Juez la resolución confirmatoria y para el efecto adjuntará copia del acta".

64 Figura colombiana, que consiste en la pérdida del derecho de propiedad, debido que, la adquisición del bien proviene de una fuente ilícita, transfiriéndose la esfera de dominio al Estado y sin ninguna contraprestación económica para su titular. Es un castigo para actividades ilícitas que desestabilizan el sistema. 
tienen una fuente lícita, si no lo hace o no lo puede hacer, el Estado, en ejercicio de su ius imperium, le extingue su derecho de propiedad alegando que los bienes son de procedencia ilícita. Inversiones a la carga de la prueba, extinción de dominio, son claros atentados contra los derechos constitucionales a la presunción de inocencia y propiedad, respectivamente.

Con ello no se quiere decir que estamos en contra de mecanismos que incidan contra los bienes de fuente ilícita, sino que, deben de darse en el marco de respeto a los derechos constitucionales antes referidos, con un debate público donde se analicen tanto argumentos de corte políticos como jurídicos, con participación obligatoria y necesaria de los organismos de control constitucional (Corte Constitucional o Tribunal Constitucional o Corte Suprema, según fuese el caso).

\section{La presunción de inocencia y su relación con el derecho a un juicio previo}

Al igual que en otros países, ${ }^{65}$ M éxico ha consagrado el derecho a un juicio previo, oral y público. Así lo establece el artículo $20^{\circ}$ constitucional, literal b), fracción V) que indica que el imputado tiene derecho a ser juzgado en audiencia pública por un juez 0 tribunal. La publicidad sólo podrá restringirse en los casos de excepción que determine la ley, por razones de seguridad nacional, seguridad pública, protección de las víctimas, testigos y menores, cuando se ponga en riesgo la revelación de datos legalmente protegidos, o cuando el tribunal estime que existen razones fundadas para justificarlo.

Del citado artículo constitucional plasma el principio de que el juicio se celebrará ante un juez que no haya conocido del caso previamente, así como, que la presentación de los argumentos y los elementos probatorios se desarrollarán de manera pública, contradictoria y oral. ${ }^{66}$

Al respecto, este derecho al juicio previo ha sido desarrollado a través de la denominada fase procesal: juzgamiento (o juicio oral ${ }^{67}$ ), cuyo objetivo es la demostración

65 Por ejemplo, la Constitución argentina, en el artículo 18, establece que: "Ningún habitante podrá ser condenado sino en virtud de juicio previo, fundado en ley anterior al hecho del proceso". Binder comenta que unos lo han interpretado como la exigencia de una sentencia previa, en el sentido de que no puede existir una condena que no sea el resultado de un juicio lógico; sin embargo, para el jurista argentino la norma constitucional se refiere al juicio como institución política-cultural (concretamente, juicio oral). Cfr. BINDER, Alberto (1993): Introducción al derecho procesal penal (Ad-Hoc, Buenos Aires), pp. 111-112.

66 Aunque ello no signifique que el derecho a un juicio previo sí pueda ser alegado en nuestro sistema debido, entre otros argumentos, que el mismo está plasmado en tratados internacionales que M éxico ha suscrito y, por ende, forma parte de nuestro Derecho. Así, tenemos: Declaración Universal de los Derechos Humanos (artículo 10); Pacto Internacional de los Derechos Civiles y Políticos (artículo 14.1); y la Convención Interamericana sobre Derechos Humanos (artículo 7.5).

67 La etapa se ha conocido bajo diferentes denominaciones, las que destacan alguna característica de la misma; así se ha hablado de "plenario", atendiendo a que tanto las partes como el órgano jurisdiccional actúan en la plenitud de sus facultades; de "debate" o "discusión", destacando la mecánica eminentemente contradictoria, y de "juicio", nombre que se ha impuesto y que deriva tanto de "juzgamiento" como de la circunstancia de que toda la actividad conduce, en definitiva, a la afirmación de reproche o absolución respecto de lo imputado. 
de la acusación penal a través de la actuación y análisis de los medios probatorios; siendo, dentro de un modelo acusatorio, la etapa central del proceso (penal).

Lamentablemente, en el Perú, Constitución Política de 1993 no ha consagrado, literalmente, el derecho a un juicio previo, aunque en su lugar consagra la garantía de no ser penado sin proceso judicial, el cual conlleva que ninguna persona sea afectada o sancionada si antes no se inició, tramitó y concluyó el proceso o procedimiento correspondiente, garantizando su intervención o participación. ${ }^{68}$ Sin embargo, esta omisión ha sido suplida en el artículo I inciso 2) del Título Preliminar del Código Procesal Penal peruano del 2004 (publicado en julio del 2004, ${ }^{69}$ el mismo que ha entrado en vigencia en los Distritos Judiciales de Huaura, La Libertad, Tacna, M oquegua y A requipa), el cual establece que "Toda persona tiene derecho a un juicio previo, oral, público y contradictorio, desarrollado conforme a las normas de este Código". ${ }^{70}$

Finalmente, y con relación a la jurisprudencia, la Primera Sala de la Suprema Corte de Justicia de la Nación (México), ha establecido lo siguiente: "Si no se celebró la audiencia pública a que alude la fracción VI del artículo 20 constitucional para ser el reo oído en defensa y juzgado, tal anomalía procesal irroga la consiguiente indefensión al acusado, en los términos de la fracción IX del artículo 160 de la Ley de A mparo, y hace procedente la concesión de la protección federal, para el único efecto de que se reponga el procedimiento a partir del momento en que se produjo la mencionada violación procesal". ${ }^{71}$

68 Bustamante Alarcón, Reynaldo (2005): Derecho a no ser sancionado o afectado sin previo proceso o procedimiento (La Constitución Comentada, Tomo II, Gaceta Jurídica, Lima), p. 546.

69 Publicado, el 29 de julio del 2004 a través del Decreto Legislativo 957.

70 En el ámbito de la legislación comparada, encontramos este derecho en los siguientes textos procesales: Código de Procedimientos Penales de Bolivia (1999): Artículo 1. “Nadie será condenado a sanción alguna si no es por sentencia ejecutoriada, dictada luego de haber sido oído previamente en juicio oral y público, celebrado conforme a la Constitución, las Convenciones y Tratados internacionales vigentes y este Código".

Código Procesal Penal de Paraguay (1998): Artículo 1. “Nadie podrá ser condenado sin un juicio previo, fundado en una ley anterior al hecho del proceso, realizado conforme a los derechos y garantías establecidos en la Constitución, el Derecho Internacional vigente y a las normas de este código.

En el procedimiento se observarán especialmente los principios de oralidad, publicidad, inmediatez, contradicción, economía y concentración, en la forma en que este código determina".

Código Orgánico Procesal Penal de Venezuela (2006): Artículo 1 (Título Preliminar). “Nadie podrá ser condenado sin un juicio previo, oral y público, realizado sin dilaciones indebidas, ante un juez o tribunal imparcial, conforme a las disposiciones de este Código y con salvaguarda de todos los derechos y garantías del debido proceso, consagrados en la Constitución de la República, las leyes, los tratados, convenios y acuerdos internacionales suscritos por la República".

71 Amparo penal directo 803/50. Por acuerdo de la Primera Sala, de fecha 8 de junio de 1953, no se menciona el nombre del promovente. 24 de junio de 1953. Mayoría de tres votos. Ausente: Luis G. Corona. Disidente: José Castro Estrada. Ponente: Teófilo Olea y Leyva. 


\section{EXCURSO: LA PRESUNCIÓN DE INOCENCIA EN LA JURISPRUDENCIA DE LA CORTE INTERAMERICANA DE DERECHOS HUMANOS}

Por otro lado, para la Corte Interamericana de Derechos Humanos, la presunción de inocencia consiste:

a) El imputado no prueba su inocencia, sino quien acusa debe acreditar la culpabilidad a través de los medios probatorios que le franquea el ordenamiento jurídico respectivo. El derecho a la presunción de inocencia es un elemento esencial para la realización efectiva del derecho a la defensa y acompaña al acusado durante toda la tramitación del proceso hasta que una sentencia condenatoria que determine su culpabilidad quede firme. Este derecho implica que el acusado no debe demostrar que no ha cometido el delito que se le atribuye, ya que el onus probandi corresponde a quien acusa. ${ }^{72}$

Una persona no puede ser condenada mientras no exista prueba plena de su responsabilidad penal. Si obra contra ella prueba incompleta o insuficiente, no es procedente condenarla, sino absolverla. ${ }^{73}$

Igual como en los pronunciamientos del Tribunal Constitucional, la Corte Interamericana de Derechos Humanos ha señalado que son a través de los actos de prueba realizados en el juicio oral (salvo los casos de prueba anticipada) los que enervan la presunción de inocencia y permiten la constitución de una declaratoria de culpabilidad.

b) La presunción de inocencia se aplica a toda resolución judicial o administrativa, a situaciones extraprocesales. El derecho a la presunción de inocencia debe aplicarse no solo al ámbito de las conductas eventualmente delictivas, sino también a la adopción de cualquier resolución administrativa o jurisdiccional, que se base en conducta de las personas y de cuya apreciación derive para ellas una afectación de sus derechos o una sanción ya que ellos son manifestación del ámbito punitivo estatal. ${ }^{74}$

El principio de presunción de inocencia opera también en las situaciones extraprocesales, constituyendo el derecho de las personas a recibir el trato de no partícipe en hechos delictivos y que no se le puedan aplicar las consecuencias o efectos jurídicos correspondientes a hechos de tal naturaleza, mientras ajuste su conducta al ordenamiento jurídico, todo ello de acuerdo al derecho a la libertad personal y seguridad individual.

\footnotetext{
72 CIDH. Caso Herrera Ulloa vs. Costa Rica, sentencia de 2 de julio de 2004, Serie C N 107, párrafo 154.

$73 \mathrm{CIDH}$. Caso Herrera Ulloa vs. Costa Rica, párrafo 153. Caso Cantoral Benavides, sentencia de 18 de agosto de 2000, Serie C N69, párrafo 120.

74 Nogueira Alcalá, Humberto. Ob. cit., p. 239.
} 
En efecto, la Corte Interamericana de Derechos Humanos ha señalado que «la presunción de inocencia puede ser violada no sólo por el juez o una Corte, sino también por otra autoridad públicas. ${ }^{75}$

El derecho a la presunción de inocencia «exige que el Estado no condene informalmente a una persona o emita juicio ante la sociedad, contribuyendo así a formar una opinión pública, mientras no se acredite conforme a la ley la responsabilidad penal de aquella». ${ }^{76}$

\section{CONCLUSIONES}

a. La presunción de inocencia como una garantía individual, como un derecho público contenido en la Constitución, a favor de las personas, exige que sea ante la autoridad que esté (de competencia penal o no) y ante el procedimiento que se le sujete (igualmente, penal o no), no se considere verosímil la atribución de cargos relacionados con la comisión de delitos, salvo decisión contraria emitida por un tribunal competente dentro de la observancia del debido proceso, así como, el ser considerados como excepcionales aquellas medidas que restringen la libertad del imputado o sus demás derechos constitucionales.

b. La recepción legislativa de la presunción de inocencia se ha dado en M éxico y Perú, en primer lugar, a través de los instrumentos internacionales que tales países han suscrito ante la comunidad internacional; $y$, en segundo lugar, por su regulación en sus constituciones políticas; sin embargo, su regulación constitucional fue más tardía en México que en Perú, dado que, mientras en el primer país recién se le ha consagrado en la reforma a la Constitución Federal del 19 de junio del 2008, en el Perú ha estado presente en las dos últimas cartas magnas la de 1979 y de 1993.

c. La presunción de inocencia, tanto en México como en Perú, han presentado un desarrollo jurisprudencial, con mayor exhaustividad en el último de los países mencionados; donde se comparten la justificación de las medidas cautelares personales, la exigencia de prueba de cargo para enervar tal presunción, el contenido de la sentencia y los efectos del in dubio pro reo.

d. En los sistemas jurídicos mexicano y peruano la presunción de inocencia se relaciona con otros derechos constitucionales, como la libertad, el honor, la propiedad y el juicio previo; donde sí se respetan los pesos y contrapesos señalados en las normas legales, el ejercicio de un derecho no vacía de contenido a otro.

75 Corte Interamericana de Derechos Humanos, caso Lori Berenson vs. Perú. Serie C N 119 . Sentencia de 24 de noviembre de 2004, párrafo 159.

76 Corte Interamericana de Derechos Humanos, caso Lori Berenson vs. Perú, párrafo 160. 
e. La Corte Interamericana de Derechos Humanos ha establecido dos principios en torno a la presunción de inocencia: En primer lugar, el imputado no prueba su inocencia, sino quien acusa debe acreditar la culpabilidad a través de los medios probatorios que le franquea el ordenamiento jurídico respectivo. Y, en segundo lugar, la presunción de inocencia se aplica a toda resolución judicial o administrativa, a situaciones extraprocesales.

\section{REFERENCIA BIBLIOGRÁFICAS}

Barona VILAR, Silvia. Prisión provisional y medidas alternativas, Editorial Bosch, BarceIona, 1987.

Baytelman, Andrés \& DuCE, Mauricio. Litigación penal, juicio oral y prueba, Fondo de Cultura Económica, México D.F., 2005.

BINDER, Alberto. Introducción al derecho procesal penal, Editorial Ad-Hoc, Buenos Aires, 1993.

Bustamante Alarcón, Reynaldo. "Derecho a no ser sancionado o afectado sin previo proceso o procedimiento", en: Aa. Vv. La Constitución Comentada, Tomo II, Editorial Gaceta Jurídica, Lima, Perú, 2005.

Cárdenas García, Jaime. "M éxico: A la luz de los modelos federales", en: Boletín Mexicano de Derecho Comparado, № 110, México D.F., México, 2004.

CÁrdenas Ruiz, Marco Antonio. "La presunción de inocencia", En: Estafeta Jurídica Virtual, Disponible en: www.amag.edu.pe [03/08/08]

Carmagnani, M arcello. Federalismos latinoamericanos, Fondo de Cultura Económica, M éxico D.F., 1993.

CAstañeda Otsu, Susana Ynes. "El proceso de habeas corpus en el Código Procesal Constitucional", en: Aa. Vv. Introducción a los procesos constitucionales. Comentarios al Código Procesal Constitucional, Jurista Editores, Lima, Perú, 2005.

CAstlLo Córdoba, Luis. Elementos de una teoría general de los derechos constitucionales, ARA Editores, Lima, 2003.

CAstillo CórdobA, Luis. Habeas corpus, amparo y habeas data, ARA Editores, Lima, 2004.

Claría O lmedo, Jorge. Tratado de derecho procesal penal, Tomo I, Editorial Ediar S.A., Buenos Aires, 1960.

Eguiguren Prael, Francisco. Estudios constitucionales, ARA Editores, Lima, 2002.

ESPINOSA-SA LDAÑA BARRERA, Eloy. "Habeas corpus contra resoluciones judiciales: entre la evolución del concepto "proceso regular" y la determinación del ámbito de acción del juez constitucional", en: Aa. Vv. Jurisdicción Constitucional, impartición de justicia y debido proceso, ARA Editores, Lima, Perú, 2003.

FerRajol, Luigi. Derecho y razón, 5a edición, Editorial Trotta, Madrid, 2001.

Gozaínı, Osvaldo Alfredo. Derecho procesal constitucional, Editorial de Belgrano, Buenos Aires, 1999.

Gozaínı, O svaldo Alfredo. "La presunción de inocencia. Del proceso penal al proceso civil", en: Revista Latinoamericana de Derecho, A ño III, № 6, Universidad Nacional Autónoma de M éxico, México D.F., M éxico, 2006. 
GuILLÉn López, Raúl. Las garantías individuales en la etapa de averiguación previa, Editorial Porrúa, México D.F., 2003.

LuCCHINI, Luigi. Elemento di procedura penale, Editorial Barbera, Florencia, 1995.

MontAÑÉs PARDo, Miguel Ángel. La presunción de inocencia. A nálisis doctrinal y jurisprudencial, Editorial Aranzadi, Pamplona, 1999.

Nogueira A lcalá, Humberto. "Consideraciones sobre el derecho fundamental a la presunción de inocencia", en: lus et praxis, № 11, Talca, Chile, 2005.

Pedraz Penalva, Ernesto. "El proceso y sus alternativas", en: Cuadernos de derecho judicial, № 27, Poder Judicial, Madrid, España, 1995.

Romero Felipa, Ana María. "Los principios constitucionales de in dubio pro reo y presunción de inocencia", en: Estafeta Jurídica Virtual, disponible en: www.amag.edu.pe [03/08/08].

Sentís Melendo, Santiago. "Qué es la prueba. Naturaleza de la prueba”, en: Revista Derecho Procesal Iberoamericana, № 2-3, M adrid, España, 1973.

VARONA MARTíneZ, Gerna. La mediación reparadora como estrategia de control social: una perspectiva criminológica, Editorial Comares, Granada, 1998. 